"Przegląd Prawa Konstytucyjnego"

- Nr $2(14) / 2013$

\title{
Recenzja
}

\section{Periodyk „The Copernicus Journal of Political Studies” 2012, nr 1(1), Wydawnictwo Adam Marszałek, Toruń 2012, ss. 173}

W 2012 r. ukazało się nowe czasopismo naukowe „The Copernicus Journal of Political Studies". Wydawcą tego periodyku jest Wydawnictwo Adam Marszałek z Torunia specjalizujące się między innymi w wydawnictwach z zakresu naukach politycznych. Redaktorem Naczelnym jest pani doktor Agnieszka Bryc. Funkcja zastępcy redaktora powierzona została pani Joannie Piechowiak-Lamparskiej. Pozostałymi członkami komitetu redakcyjnego są Bartosz Bojarczyk, Dorota Niedziółka, Radosław Potorski oraz Agata Włodkowska-Bagan. Komitet redakcyjny zamierza wydawać „The Copernicus Journal of Political Studies" jako półrocznik.

Moim zdaniem czasopismo może stać się w niedługiej przyszłości miejscem wymiany poglądów naukowców zajmujących się badaniami z nauk politycznych oraz zostać głosem w debacie o państwie i polityce. Czasopisma naukowego o takim zakresie tematycznym istnieją już na polskim rynku wydawniczym. Jednakże zaletą "The Copernicus Journal of Political Studies" jest to, iż wydawany jest w języku angielskim, co daje możliwość dostępu szerszej grupie autorów oraz czytelników nie tylko w Polsce, ale przede wszystkim za granicą. Tak więc ta nowa inicjatywa tym bardziej zasługuje na aprobatę.

Przedstawiony mi do recenzji pierwszy numer „The Copernicus Journal of Political Studies” składa się z dwunastu artykułów podzielonych na dwie grupy tematyczne: „Polish Foreign Policy” (Polska Polityka Zagraniczna) oraz „Issues of Regional Integration” (Problemy Integracji Regionalnej).

Pierwszą grupę otwiera tekst Iwony Galewskiej Polish Treaty Policy Towards Czech Republic in 1993-2011. Artykuł jest analizą polityki traktatowej 
Polski i Czach. Autorka stwierdza, iż warunkiem pozytywnych relacji dwustronnych jest prawidłowo prowadzona polityka traktatowa, która jako część polityki zagranicznej odpowiada za zapewnienie maksymalnie korzystnych warunków międzynarodowych dla rozwoju kraju we wszystkich jego dziedzinach. Artykuł przedstawia wybrane obszary bilateralnej współpracy Polski i Czech w latach 1993-2011, analizuje tą współpracę oraz weryfikuje zaangażowanie obu stron.

Tomasz Kamiński w tekście Are Poland and Canada: Becoming Close Partners? przedstawia stosunki pomiędzy Kanadą a Polską w XXI wieku. Autor wyjaśnia związki pomiędzy tymi państwami oraz ich genezę. Następnie analizuje relacje gospodarcze, a także miejsce społeczności polskiej w kanadzie. Ostatnia część artykułu to omówienie aktualnych stosunków polsko-kanadyjskich ze szczególnym wyróżnieniem dwóch zdarzeń, czyli sprawy śmierci emigranta polskiego na lotnisku w Vancouver oraz przejęcia kanadyjskiej spółki wydobywczej Quadra FNX przez polskie KGHM.

W artykule Latin American Direction in the Polish Foreign Policy. Relations with Latin American and Caribbean States after 2004 Anna Ratke-Majewska przestawia aspekt polityczny relacji Polski z państwami latynoamerykańskimi od chwili jej przystąpienia do Unii Europejskiej. Autorka skupia się na wpływie polskiej akcesji na dynamikę oraz rozwój wzajemnych stosunków.

Kolejnym tekstem jest artykuł Olgi Svystun pt. Partnership Cooperation of Lublin and Western Ukraine. Autorka podjęła sie próby przybliżenia działalności miasta Lublin w zakresie współpracy z największym partnerem na Wschodzie, a mianowicie Ukrainą. Przejawy tej współpracy widoczne są w kontaktach oficjalnych miasta oraz instytucji, firm, a także osób prywatnych, które dbają o rozwój dobrosąsiedzkich stosunków.

Luiza A. Wawrzyńska-Furman w opracowaniu Pope John Paul II's Teaching and Gestures: The Influence on Polish-Jewish Reconciliation ukazuje znaczenie nauki i gestów Papieża Jana Pawła II dla pojednania polsko-żydowskiego. Prezentuje najważniejsze papieskie akty związane z judaizmem i wspólnotą żydowska. Autorka przedstawia Jana Pawła II nie tylko jako teologa, etyka, wpływowego religijnego przywódcę, ale również jako moralny autorytet Polaków i polityka, który dał przykład przyjaznego nastawienia do Żydów i państwa Izrael. 
Artykuł The Usage of Politics of Memory in Polish Foreign Policy: Present State and Perspectives Patryka Wawrzyńskiego przedstawia wykorzystanie polityki historycznej jako uzasadnienia polityki zagranicznej Polski oraz jej perspektywy na kolejne lata. Ukazuje zmiany, jakie zaszły w polityce od „konserwatywnej” wizji prezydenta L. Kaczyńskiego do „pojednawczej” premiera D. Tuska. Wskazuje również wydarzenia w polskiej historii, których rocznice mogłyby zostać wykorzystane do ukazania polskiej wizji przyszłości, a także wsparcia polityki zagranicznej.

Drugą grupę tematyczną - „Issues of Regional Integration” (Problemy Integracji Regionalnej) - rozpoczyna tekst Radosława Potorskiego Evolution of an Approach to the Problem of Relations which Public Authority May Enter, as a Condition for EU Membership. Autor stwierdza, iż obecnie państwa zaczynają funkcjonować w mniejszym stopniu jako suwerenne byty, a w większym jako składniki międzynarodowej społeczności politycznej. W tym samym czasie następuje angażowanie się podmiotów poza-rządowych w podejmowanie wiążących decyzji publicznych. Odejście od centrycznie rozumianego modelu podejmowania decyzji w państwie narodowym warunkuje zrozumienie współczesnych relacji, w jakich państwa mogą brać udział. Dla wyjaśnienia tego zjawiska używana jest zdaniem Autora koncepcja państwa wydrążonego.

Tekst Helen Sääsk: National Power. Options for The Republic of Estonia in Case of a Pandemic jest analizą hipotetycznej sytuacji, w której Republika Estonii otrzymuje informację ze Światowej Organizacji Zdrowia o pandemii grypy. Tekst ciekawy, przedstawia, jak rząd starałby się użyć wszystkich możliwych instrumentów władzy w celu ochrony obywateli. Autorka charakteryzuje Estonię jako państwo-łącznik idei i wartości związanych z ochroną zdrowia pomiędzy Skandynawią a Wschodnią Europą.

Dmitrij Aleksandrowich Bespalov w artykule The Development of Kyrgyzstan: Integration Processes and Establishment of Customs Unions przedstawił perspektywy rozwoju gospodarczego Kirgistanu w kontekście postępujących procesów globalizacji i podziału pracy. Autor prezentuje teoretyczne podstawy wzrostu gospodarczego, stabilności społecznej i zrównoważenia gospodarki narodowej Kirgistanu. Następnie przedstawia szanse płynące z globalizacji i integracji oraz strukturę kirgiskiego handlu i międzynarodowej współpracy gospodarczej. W konkluzji Autor stwierdza, iż przystąpienie 
do Unii Celnej EurAsEG może wywołać poważne konsekwencje dla gospodarki analizowanego państwa.

Artykuł Ethnocentrism and the Problem of Central Asisn Integration: Current Status autorstwa Igora Viktorowych Halanskii i N.P. Han-a przedstawia problem integracji regionalnej w Azji Centralnej, który jest bardzo aktualny w kontekście tendencji światowych dążących do scalania regionów w organizacje ścisłej współpracy różnego typu. Autorzy stwierdzają, iż proces ten w państwach takich jak np. Kazachstan czy Turkmenistan nastąpi nieprędko. Jednak perspektywa rozwoju regionu środkowoazjatyckiego jako spójnej całości może mieć znaczący wpływ na kształt systemu międzynarodowego.

Kolejny tekst w recenzowanym periodyku - Participation of the Kyrgyz Republic in Integration Processes: Realities and Prospects, którego Autorem jest Nurżamal Sabyrovna Attokurova - dotyczy specyfiki integracji gospodarczej krajów Wspólnoty Niepodległych Państw, jak również przedstawia przyczyny niskiej efektywności procesów integracyjnych w tym obszarze. Ukazano także problemy, z jakimi boryka się Kirgistan i ich wpływ na jego udział w procesach integracji regionalnej.

Małgorzata Kamola-Cieślik w artykule The Economic Policies of Candidates Running for the Office of the President of the Republic of Poland in 2010 przybliża założenia polityki gospodarczej kandydatów na urząd prezydenta w wyborach w 2010 r. w Polsce. Opracowanie przedstawia deklaracje kandydatów dotyczące rozwiązywania problemów gospodarczych, ich podobieństwa i różnice oraz ukazuje analizę tych propozycji.

Całości recenzowanego periodyku dopełniają cztery recenzje. Pierwsza $\mathrm{z}$ nich - Word Power Status of China on the International Arena autorstwa Joanny Piechowiak-Lamparskiej - dotyczy opracowania Joanny Marszałek-Kawy Contemporary China. The Condition of the State, Torun 2011. Kolejna recenzja - Do International Systems Matter? autorstwa Tomasza Pawłuszki, przybliża monografię Barry'ego Buzana, Richarda Little Systemy międzynarodowe w historii świata, Warszawa 2011. Następna recenzja - Changing Vectors of German Foreign Policy, której Autorem jest Natalia Seklecka, dotyczy publikacji Jadwigi Kiwerskiej, Bogdana Koszela, Marii Tomczak, Stanisława Żerko, Polityka zagraniczna zjednoczonych Niemiec, Poznań 2011. Ostatnia recenzja - Are There Changes in Belarus? Sylwii Zakrzewskiej przedstawia monografię Eugeniusza Mironowicza Polityka zagraniczna Białorusi 1990- 
-2010, Białystok 2011. Wszystkie teksty zasługują na uznanie, zostały przygotowane profesjonalnie i zgodnie $\mathrm{z}$ wymogami przewidzianymi dla tego typu tekstów.

Czasopismo zamykają dwa sprawozdania. Pierwsze, autorstwa Patryka Wawrzyńskiego, dotyczy $3^{\text {rd }}$ Trialog International Conference: Between Oder and Neman: Issues of Cultural Memory, która odbyła się w Kaliningradzie w dniach 26-29 kwietnia 2012 r., drugie, Judyty Węgłowskiej, zdaje relację z Międzynarodowej Konferencji Naukowej nt. Ustrój terytorialny państwa a decentralizacja systemu władzy publicznej, która odbyła się w Toruniu w dniu 14 maja $2012 \mathrm{r}$.

Teksty składające się na pierwszy numer „The Copernicus Journal of Political Studies" stanowią rzetelne opracowania analizowanej tematyki. Żywię nadzieję, iż kolejne numery periodyku utrzymają poziom merytoryczny, dzięki czemu stanie się on znaczącym źródłem wiedzy o poglądach naukowców na miejsce i znaczenie polityki w współczesnym świecie.

Sabina Grabowska (Uniwersytet Rzeszowski) 